\title{
Studies with the maximal histamine test
}

\author{
B. J. VAKIL AND A. M. MULEKAR \\ From the Department of Medicine, J.J. Group of Hospitals and \\ Grant Medical College, Bombay, India
}

EDITORIAL SYNOPSIS The maximal acid output in Indian controls and subjects with duodenal ulcer is lower than that reported from the West. There is a significantly higher acid output in men than in women of comparable age and weight groups. After 50 years of age, there is a falling-off in acid output in both sexes. No significant decline in acid outputs could be established with age in subjects under 50 years of age. There is an increase in acid output with increase in weight in both sexes, more pronounced for females. Male smokers have a higher acid output than men who do not smoke, but the difference is not significant. There is no difference in acid output between vegetarians and non-vegetarians.

Since its introduction in 1953, the augmented histamine test (Kay's test) has gained widespread acceptance all over the world as the most efficient test for assessing gastric acid secretion.

Many objections have been raised against the conventional fractional test meal. The position of the tip of the tube is not accurately known and the sample may not represent the secretion of the stomach. The stimulus used in this test is neither natural nor maximal and test meals used as stimuli neutralize gastric acidity. Titration of turbid fluid containing a residue of the stimulus is difficult.

In 1953 Kay developed the augmented histamine test in which a tube is passed under fluoroscopic control and histamine is used as the stimulus in a dose sufficient to effect the maximal secretory response. Histamine is the ideal stimulus and perhaps the final chemo-stimulus of parietal cells of gastric mucosa. By means of dose response curves, Kay has shown that a dose of $0.04 \mathrm{mg}$. histamine acid phosphate per kilogram body weight has a maximal stimulatory effect on the secretion of gastric acid. This maximum acid response to the augmented dose of histamine has been confirmed in human beings by Adam, Card, Riddell, Roberts, Strong, and Woolf (1954) and by Murray, Erskine, and Fielding (1957) and in dogs by Marks, Komarov, and Shay (1960) and is supposed to represent the secretion of all the parietal cells in the stomach.

Several workers from such far and distant places as Edinburgh (Bruce, Card, Marks, and Sircus, 1959), Glasgow (Kay, 1953), and Philadelphia (Marks, 1961) have reported their results with the Kay test and have found comparable values in acid output in control and in ulcer subjects. Most published reports have not taken into account the variations in acid output due to age, weight, and sometimes even to sex. Bloomfield and Keefer (1928a, 1928b), Polland, (1933), and Levin, Kirsner, and Palmer (1951) have shown with a submaximal histamine test that the acid output declines with age and that normal men have a higher acid output than women.

This paper describes some of the results in 238 augmented histamine tests performed with Kay's technique in 208 hospital subjects in Bombay. The range of acid output. in a normal Indian population, analysed by age, sex, and body weight, is presented. The relationship of acid output to dietetic and smoking habits in controls is reported. Acid output in subjects with various diseases is also presented.

\section{METHOD}

The technique employed was essentially the same as that described by Kay (1953). After an overnight fast a radioopaque Ryle's tube, size 16-18 Fr., is passed through the nose into the stomach under fluoroscopic control. Its tip is adjusted so as to lie in the most dependent part of the stomach, which is generally on the right paravertebral border. The position is confirmed by aspirating the pool of fasting juice. Ryle's tube is now fixed by strapping the tube to the side of the nose with adhesive tape. The patient is allowed to lie on his left side and is urged to expectorate saliva collecting in the mouth. Basal secretion is collected for one hour by continuous aspiration with a vacuum of 30 to $50 \mathrm{~mm}$. of $\mathbf{H g}$. An antihistaminic, $100 \mathrm{mg}$. of antazoline (Antistine), is given intramascularly 30 minutes after the start of the basal collection. At the end of one hour histamine acid phosphate $(0.04 \mathrm{mg}$.) kg. body weight) is given subcutaneously. Four samples, 
at intervals of 15 minutes, are collected by continuous aspiration in the following one hour. 'Free' and 'total' acidity of all the samples is measured by titrating against freshly prepared $\mathrm{N} / 10 \mathrm{NaOH}$, using Topfer's reagent and phenolphthalein as indicators. Total acid output of each sample is calculated in milliequivalents. The output over the hour after injection of histamine has been designated the 'maximal acid output' (MAO). In samples where no free acid was present, the $p \mathrm{H}$ of each sample was recorded.

\section{MATERIAL}

The number of cases studied was as follows:-

$\begin{array}{lr}\text { Category } & \text { No. } \\ \text { Normal subjects } & \text { Cas } \\ \text { Duodenal ulcer } & 151 \\ \text { Radiologically negative dyspepsias } & 32 \\ \text { Gastric carcinoma } & 18 \\ \text { Gastric ulcer } & 2 \\ \text { Stomal ulcer } & 2 \\ & 3\end{array}$

The normal subjects were selected mainly from medical and occasionally from surgical in-patients giving no history of dyspepsia and not suffering from anaemia or gastro-intestinal disease and not receiving any treatment which might influence gastric secretion. Subjects were drawn from various age and sex groups having a variety of habits and domicile so as to make it representative of the population residing in Bombay. Smokers have been defined as those smoking five or more cigarettes or the equivalent in tobacco daily for at least 12 months.

Table I shows the age and sex distribution of the normal cases studied. There is a fair distribution of cases in all age groups, except the age groups 21-30 and 51-60 where a large number of patients were admitted with a view to studying the influence of weight on acid output. Although it was desired to have a comparable number of vegetarians and non-vegetarians, the latter are more numerous as this hospital caters for a predominantly Muslim population. Comparison of acid output in smokers and non-smokers is confined to males only as all females included in the trial did not smoke.

\section{TABLE I}

AGE AND SEX DISTRIBUTION OF 151 NORMAL SUBJECTS

\begin{tabular}{llllllllll}
\multicolumn{1}{c}{ Age Group $(y r)}$. \\
\cline { 2 - 8 } & $0-10$ & $11-20$ & $21-30$ & $31-40$ & $41-50$ & $51-60$ & $61-70$ & Total \\
\hline Males & 2 & 9 & 36 & 9 & 7 & 16 & 4 & 83 \\
Females & 0 & 14 & 25 & 6 & 5 & 14 & 4 & 68
\end{tabular}

In cases with gastro-duodenal pathology, diagnosis was based on $x$-ray examination and confirmed in 12 cases on operation.

\section{RESULTS}

GENERAL OBSERVATIONS In 25 control cases and in five cases with duodenal ulcer, the test was repeated a second time after an interval of one to seven days. The volume, acidity, and acid output of basal secretions of the two tests varied widely (range: 5 to $20 \%$ ) both in controls and in cases of duodenal ulcer. However the repeatability of measurements for maximal acid secretion were fairly comparable, the average difference between the two tests in the control group being $9.3 \%$ (range: 1.8 to $10 \%$ ) and in the group with duodenal ulcer $6 \%$ (range: $2 \cdot 3$ to $7 \cdot 8 \%$ ).

The augmented histamine test, although not difficult to perform, needs careful supervision throughout its performance by a trained staff. Initially, results of the test in 30 subjects had to be scrapped as it was feared later that collection was not proper. To ensure complete aspiration of gastric juice by suction, constant supervision is essential. As negative pressure builds up in the stomach, mucosa gets sucked on to the mouth of the Ryle's tube and the flow of juice stops. It is then necessary to disconnect the tube and inject some air and start the suction again. This must be done many times during the test. A small-bore Ryle's tube is unsuitable as it often gets blocked with mucus. Ryle's tube, size 16-18 Fr., was found to be the most suitable, although it was somewhat inconvenient for the patient.

Intubation was not a difficult problem. The tube was first passed blindly and patients were then screened. Only in $30 \%$ of the tests was the tip found to be in a satisfactory position and little manipulation was required under fluoroscopy to be sure that it was in the most dependent part. In the rest $(70 \%)$, the tip was found to be in an unsatisfactory position: the lower oesophagus (3\% tests), the fundus ( $30 \%$ tests), or the body of the stomach (22\% tests) or the duodenum or pylorus (15\% tests). Of these cases, in 106 the tube could be manoeuvred into a satisfactory position with little manipulation but 58 cases needed considerable manipulation before the tip could be brought into a satisfactory position.

In 10 cases, the test had to be abandoned because the patients did not cooperate. In one case with pyloric stenosis the tube was passed successfully but no aspiration could be obtained as the opening was blocked by food particles. The test was later performed successfully with proper preparation of the patient.

Histamine was generally well tolerated by all patients; mild histamine reactions such as flushing, sensations of heat, headache, and mild tachycardia were seen in about a quarter of the patients. These reactions were more common when antihistaminic cover of antazoline was used in $50 \mathrm{mg}$. doses but became less when the dose was increased to $100 \mathrm{mg}$. 
TABLE II

MEAN BASAL AND MEAN MAXIMUM ACID OUTPUTS IN VARIOUS GROUPS OF NORMALS AND PATIENTS

\begin{tabular}{|c|c|c|c|c|c|}
\hline Material & $\begin{array}{l}\text { No. of } \\
\text { Cases }\end{array}$ & $\begin{array}{l}\text { Mean Basal } \\
\text { Total Acid Output } \\
\text { (mEq.) }\end{array}$ & S.D. & $\begin{array}{l}\text { Mean Maximal } \\
\text { Total Acid Output } \\
\text { (mEq.) }\end{array}$ & S.D. \\
\hline \multicolumn{6}{|l|}{ Hospital controls } \\
\hline Males and females & 151 & $\begin{array}{l}2.64 \\
(0.05-25)\end{array}$ & $3 \cdot 3$ & $\begin{array}{l}8 \cdot 74 \\
(0 \cdot 16-29 \cdot 4)\end{array}$ & $7 \cdot 0$ \\
\hline Males & 83 & $\begin{array}{l}3 \cdot 31 \\
(0.05-25)\end{array}$ & 3.882 & $\begin{array}{l}10 \cdot 22 \\
(0 \cdot 16-29 \cdot 4)\end{array}$ & $8 \cdot 237$ \\
\hline Females & 68 & $\begin{array}{l}1.81 \\
(0 \cdot 10-17 \cdot 51)\end{array}$ & 1.432 & $\begin{array}{l}7 \cdot 00 \\
(0 \cdot 73-22 \cdot 19)\end{array}$ & $4 \cdot 409$ \\
\hline Smokers (males only) & 40 & $\begin{array}{l}3.77 \\
(0.05-24.96)\end{array}$ & $4 \cdot 605$ & $\begin{array}{l}12 \cdot 72 \\
(0 \cdot 48-29 \cdot 4)\end{array}$ & $8 \cdot 874$ \\
\hline Non-smokers (males only) & 44 & $\begin{array}{l}2 \cdot 87 \\
(0 \cdot 06-12 \cdot 20)\end{array}$ & $2 \cdot 509$ & $\begin{array}{l}7 \cdot 77 \\
(0 \cdot 32-19 \cdot 68)\end{array}$ & $5 \cdot 602$ \\
\hline Vegetarians & 40 & $\begin{array}{l}3 \cdot 65 \\
(0 \cdot 21-13 \cdot 44)\end{array}$ & 3.065 & $\begin{array}{l}10 \cdot 03 \\
(0 \cdot 48-22 \cdot 19)\end{array}$ & 5.669 \\
\hline Non-vegetarians & 111 & $\begin{array}{l}2.88 \\
(0.05-25)\end{array}$ & 2.969 & $\begin{array}{l}9 \cdot 00 \\
(0 \cdot 16-29 \cdot 4)\end{array}$ & 6.074 \\
\hline \multicolumn{6}{|l|}{ Duodenal ulcer } \\
\hline Males & 24 & $\begin{array}{l}5 \cdot 21 \\
(1 \cdot 62-71 \cdot 53)\end{array}$ & $5 \cdot 83$ & $\begin{array}{l}17 \cdot 85 \\
(7 \cdot 03-38 \cdot 40)\end{array}$ & $8 \cdot 30$ \\
\hline Females & 8 & $\begin{array}{l}3.35 \\
(2 \cdot 80-3 \cdot 89)\end{array}$ & 0.5 & $\begin{array}{l}17 \cdot 76 \\
(15 \cdot 59-19 \cdot 93)\end{array}$ & $2 \cdot 2$ \\
\hline Radiologically negative dyspepsia & 18 & $\begin{array}{l}3.77 \\
(0 \cdot 26-12 \cdot 96)\end{array}$ & & $\begin{array}{l}16 \cdot 00 \\
(0 \cdot 22-33 \cdot 22)\end{array}$ & \\
\hline Gastric ulcer & 2 & $\begin{array}{l}3.26 \\
(0.91-5 \cdot 62)\end{array}$ & & $\begin{array}{l}10 \cdot 48 \\
(3 \cdot 87-17 \cdot 10)\end{array}$ & \\
\hline Stomal ulcers & 3 & $\begin{array}{l}3 \cdot 70 \\
(0 \cdot 672-9 \cdot 46)\end{array}$ & & $\begin{array}{l}9 \cdot 67 \\
(0 \cdot 30-18 \cdot 10)\end{array}$ & \\
\hline Gastric carcinoma & 2 & $\begin{array}{l}4 \cdot 47 \\
(3 \cdot 42-5 \cdot 52)\end{array}$ & & $\begin{array}{l}14 \cdot 45 \\
(2 \cdot 02-26.89)\end{array}$ & \\
\hline
\end{tabular}

TABLE III

ACID OUTPUT RELATED TO AGE

\begin{tabular}{|c|c|c|c|c|c|c|c|c|c|c|c|c|}
\hline & \multicolumn{12}{|c|}{ Age Group (yr.) } \\
\hline & \multicolumn{3}{|l|}{$0-10$} & \multicolumn{3}{|l|}{$11-20$} & \multicolumn{3}{|l|}{$21-30$} & \multicolumn{3}{|l|}{$31-40$} \\
\hline & \multirow{2}{*}{$\begin{array}{l}\text { Weight } \\
\text { (kg.) }\end{array}$} & \multicolumn{2}{|c|}{ Acid Output (mEq.) } & \multirow{2}{*}{$\begin{array}{l}\text { Weight } \\
(\mathrm{kg} .)\end{array}$} & \multicolumn{2}{|c|}{ Acid Output (mEq.) } & \multirow{2}{*}{$\begin{array}{l}\text { Weight } \\
\text { (kg.) }\end{array}$} & \multicolumn{2}{|c|}{ Acid Output (mEq.) } & \multirow{2}{*}{$\begin{array}{l}\text { Weight } \\
\text { (kg.) }\end{array}$} & \multicolumn{2}{|c|}{ Acid Output (mEq.) } \\
\hline & & Basal & Maximal & & Basal & Maximal & & Basal & Maximal & & Basal & Maximal \\
\hline \multirow[t]{4}{*}{$\begin{array}{l}\text { Males } \\
\text { Females }\end{array}$} & $\begin{array}{l}25 \\
0\end{array}$ & $\begin{array}{l}1 \cdot 83 \\
0\end{array}$ & $\begin{array}{l}5.67 \\
0\end{array}$ & $\begin{array}{l}40 \\
36 \cdot 5\end{array}$ & $\begin{array}{l}4 \cdot 33 \\
2 \cdot 12\end{array}$ & $\begin{array}{r}10 \cdot 56 \\
7 \cdot 14\end{array}$ & $\begin{array}{l}46 \\
42\end{array}$ & $\begin{array}{l}4.07 \\
1.87\end{array}$ & $\begin{array}{r}11 \cdot 63 \\
7.86\end{array}$ & $\begin{array}{l}58 \\
46\end{array}$ & $\begin{array}{l}4 \cdot 00 \\
2 \cdot 88\end{array}$ & $\begin{array}{l}14 \cdot 64 \\
10 \cdot 02\end{array}$ \\
\hline & \multicolumn{9}{|c|}{ Age Group (yr.) } & & & \\
\hline & \multicolumn{3}{|l|}{$41-50$} & \multicolumn{3}{|l|}{$51-60$} & \multicolumn{3}{|l|}{$61-70$} & & & \\
\hline & $\begin{array}{l}\text { Weight } \\
\text { (kg.) }\end{array}$ & \multicolumn{2}{|c|}{ Acid Output (mEq.) } & \multirow{2}{*}{$\begin{array}{l}\begin{array}{l}\text { Weight } \\
(k g .)\end{array} \\
57 \\
44\end{array}$} & \multicolumn{2}{|c|}{ Acid Output (mEq.) } & \multirow{2}{*}{ 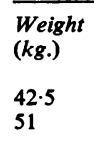 } & \multicolumn{2}{|c|}{ Acid output (mEq.) } & & & \\
\hline $\begin{array}{l}\text { Males } \\
\text { Females }\end{array}$ & $\begin{array}{l}60 \\
48\end{array}$ & $\begin{array}{l}\text { Basal } \\
3.48 \\
1.49\end{array}$ & $\begin{array}{l}\text { Maximal } \\
16 \cdot 60 \\
9 \cdot 34\end{array}$ & & $\begin{array}{l}\text { Basal } \\
2 \cdot 30 \\
1 \cdot 00\end{array}$ & $\begin{array}{l}\text { Maximal } \\
7.92 \\
5.40\end{array}$ & & $\begin{array}{l}\text { Basal } \\
2.64 \\
1.50\end{array}$ & $\begin{array}{l}\text { Maximal } \\
7 \cdot 50 \\
5 \cdot 14\end{array}$ & & & \\
\hline
\end{tabular}

TABLE IV

ACID OUTPUT RELATED TO WEIGHT

\begin{tabular}{|c|c|c|c|c|c|c|c|c|c|c|c|c|}
\hline & \multicolumn{12}{|c|}{ Weight Group (kg.) } \\
\hline & \multicolumn{2}{|l|}{$21-30$} & \multicolumn{2}{|l|}{$31-40$} & \multicolumn{2}{|l|}{$41-50$} & \multicolumn{2}{|l|}{$51-60$} & \multicolumn{2}{|l|}{$61-70$} & \multicolumn{2}{|l|}{$71-80$} \\
\hline & \multicolumn{2}{|c|}{ Acid Output (mEq.) } & \multicolumn{2}{|c|}{$\overline{\text { Acid Output (mEq.) }}$} & \multicolumn{2}{|c|}{$\overline{\text { Acid Output (mEq.) }}$} & \multicolumn{2}{|c|}{ Acid Output (mEq.) } & \multicolumn{2}{|c|}{ Acid Output (mEq.) } & \multicolumn{2}{|c|}{ Acid Output (mEq.) } \\
\hline & Basal & Maximal & Basal & Maximal & Basal & Maximal & Basal & Maximal & Basal & Maximal & Basal & Maximal \\
\hline $\begin{array}{l}\text { Males } \\
\text { Females }\end{array}$ & $\begin{array}{l}1 \cdot 76 \\
\theta \cdot 62\end{array}$ & $\begin{array}{l}7 \cdot 22 \\
3 \cdot 14\end{array}$ & $\begin{array}{l}2 \cdot 28 \\
1 \cdot 28\end{array}$ & $\begin{array}{l}8 \cdot 62 \\
4 \cdot 45\end{array}$ & $\begin{array}{l}2 \cdot 85 \\
1 \cdot 51\end{array}$ & $\begin{array}{r}10 \cdot 84 \\
6 \cdot 31\end{array}$ & $\begin{array}{l}3 \cdot 4 \\
2 \cdot 06\end{array}$ & $\begin{array}{r}11 \cdot 39 \\
8.90\end{array}$ & $\begin{array}{l}3 \cdot 8 \\
3 \cdot 38\end{array}$ & $\begin{array}{l}13 \cdot 2 \\
10 \cdot 82\end{array}$ & $\begin{array}{l}3.96 \\
-\end{array}$ & $\underline{-}^{11 \cdot 26}$ \\
\hline
\end{tabular}


TABLE V

ACID OUTPUT RELATED TO WEIGHT IN TWO AGE GROUPS

Weight (kg.)

\begin{tabular}{|c|c|c|c|c|c|c|c|c|c|c|c|c|c|}
\hline \multirow{3}{*}{$\begin{array}{l}\text { Age } \\
\text { Group } \\
(y r .)\end{array}$} & & \multirow{2}{*}{\multicolumn{2}{|c|}{$\frac{21-30}{\text { Acid Output ( } \mathrm{mEq} \text {.) }}$}} & \multirow{2}{*}{\multicolumn{2}{|c|}{$\frac{31-40}{\text { Acid Output (mEq.) }}$}} & \multirow{2}{*}{\multicolumn{2}{|c|}{$\frac{41-50}{\text { Acid Output (mEq.) }}$}} & \multirow{2}{*}{\multicolumn{2}{|c|}{$\frac{51-60}{\text { Acid Output (mEq.) }}$}} & \multirow{2}{*}{\multicolumn{2}{|c|}{$\frac{61-70}{\text { Acid Output (mEq.) }}$}} & \multirow{2}{*}{\multicolumn{2}{|c|}{$\frac{71-80}{\text { Acid Output (mEq.) }}$}} \\
\hline & & & & & & & & & & & & & \\
\hline & & Basal & Maximal & Basal & Maximal & Basal & Maximal & Basal & Maximal & Busal & Maximal & Basal & Maximal \\
\hline $\begin{array}{l}21-30 \\
51-60\end{array}$ & $\begin{array}{l}\text { Males } \\
\text { Females } \\
\text { Males } \\
\text { Females }\end{array}$ & $\begin{array}{l}-1 \\
1.63 \\
-1 \\
-1\end{array}$ & $\begin{array}{l}-1 \\
2 \cdot 65 \\
-1 \\
-1\end{array}$ & $\begin{array}{l}1 \cdot 61 \\
2 \cdot 38 \\
-1 \\
1 \cdot 21\end{array}$ & $\begin{array}{l}8 \cdot 74 \\
5 \cdot 29 \\
-1 \\
2 \cdot 31\end{array}$ & $\begin{array}{l}3 \cdot 16 \\
2 \cdot 24 \\
1 \cdot 5 \\
0 \cdot 85\end{array}$ & $\begin{array}{l}9 \cdot 7 \\
6 \cdot 12 \\
6 \cdot 99 \\
5 \cdot 13\end{array}$ & $\begin{array}{l}3 \cdot 82 \\
2 \cdot 00 \\
2 \cdot 4 \\
1 \cdot 30\end{array}$ & $\begin{array}{r}10 \cdot 75 \\
6 \cdot 55 \\
9 \cdot 00 \\
8 \cdot 59\end{array}$ & $\begin{array}{l}3 \cdot 79 \\
-1 \\
2 \cdot 8 \\
2 \cdot 0\end{array}$ & $\begin{array}{l}11 \cdot 6 \\
-16 \cdot 16 \\
10 \cdot 2\end{array}$ & $\begin{array}{l}4 \cdot 16 \\
-1 \\
3 \cdot 9 \\
-1\end{array}$ & $\begin{array}{l}13 \cdot 2 \\
-_{12}^{1} \\
-1\end{array}$ \\
\hline
\end{tabular}

Severe histamine reactions such as a marked fall in blood pressure or vomiting necessitating discontinuation of the test were observed only in three cases. Delayed urticaria was seen in four cases. On the whole antazoline was well tolerated. Mild drowsiness was noted in $25 \%$ of the cases.

NORMAL RANGE It is difficult to give a true range of normal for gastric acid output as a number of factors have been reported to influence the secretion. Hence in this study the results have been broken down, under various variable factors such as sex, age, and weight groups. Further, an attempt is made to study the influence of each factor by eliminating other variables. In order to separate the influence of age from weight, a large number of subjects have been studied in two age groups, namely, 21-30 and 51-60 years, and results charted against weight groups.

Table II shows the basal and maximal acid output expressed as milliequivalents for the whole group and for its various subclassifications.

The mean basal secretion for the whole group was $2.64 \mathrm{mEq}$. (S.D. 3.3, range 0.05 to 25 ). The mean maximal acid output was $8.74 \mathrm{mEq}$. (S.D. 7.0, range: $0 \cdot 16$ to $29 \cdot 4$ ). The range of readings both for basal and maximal acid output is wide.

SEX DIFFERENCES There are significant differences between basal secretions $(P<0.001)$ and maximal acid outputs $(P<0.01)$ in men and women (Table II). However, such a comparison does not take into consideration variables like the age and weight of the subjects. Tables III and IV show that for each of the subgroups for age and weight, males secrete 1.5 to 2 times more acid than corresponding females. These tables, however, have two variables and thus do not convincingly prove the sex differences. Table $\mathrm{V}$ is a comparison between males and females of similar age and weight groups and it shows that men secrete more acid than do women in each of the groups.

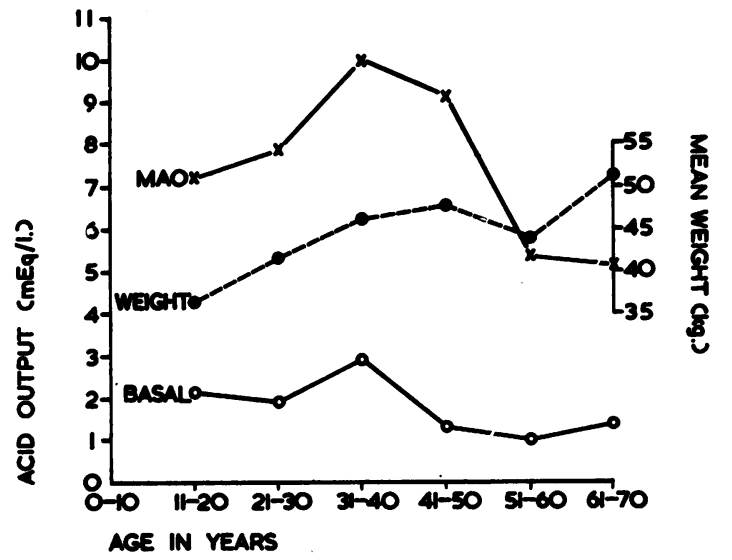

FiG. 1. Basal acid output for men.

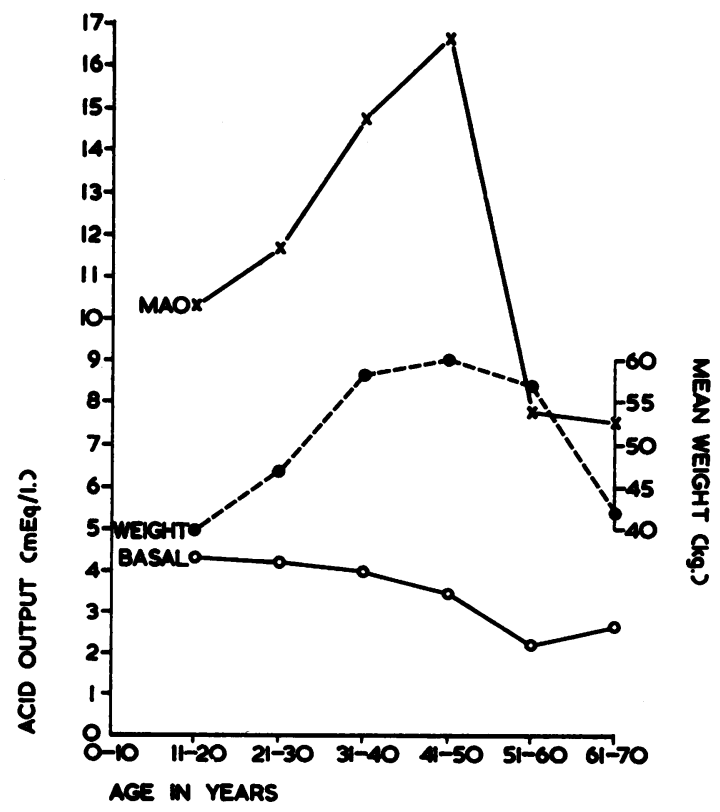

FIG. 2. Basal acid output for women. 
INFLUENCE OF AGE In the present series basal acid outputs for men and women show on the whole a gradual decline with increasing age (Figs. 1 and 2).

The decrease in basal acid output in men for the whole group is slight (basal acid output $r=-0 \cdot 17$; $P>0.09$ ) and is not significantly different from zero. In women there is a significant decrease in basal acid output $(\mathrm{r}=-0.24 ; \mathrm{P}<0.05)$.

If the subjects are arbitarily divided at the age of 50 , it can be calculated that basal acid output over 50 years in both sexes is significantly less $(\mathrm{P}<0.05)$ than in those under 50 years age (below 50 years for males, $3.87 \mathrm{mEq}$. for females, $2.0 \mathrm{mEq}$.; over 50 years for males, $1.89 \mathrm{mEq}$. for females, $1.01 \mathrm{mEq}$ ).

Maximal acid output in both sexes does not show a linear correlation; in fact, there is an increase in acid output with age up to the age of 50 years (men, $\mathrm{r}=+0.16, \mathrm{P}>0.2$; women, $\mathrm{r}=+0.54$, $P<0.001)$. Maximal acid output in males under 50 years shows a wide scatter (Fig. 3) compared with females of a similar age group (Fig. 4). Maximal acid output in both sexes shows a steep decline after the age of 50 years (men, $\mathrm{r}=-0.02, \mathrm{P}>0.9$; women, $r=-0.84, P<0.001)$.

Mean weights of subjects of various age groups studied are also charted in Figs. 1 and 2 for comparison. The parabolic curve of the maximal acid output correlates well with the parabolic curve of the weight in both sexes. The increase in maximal acid output in both sexes under 50 years can be closely correlated with the increase in mean weight in these groups but the decline in both sexes after the age of 50 years seems to be out of proportion to the decrease in their mean weights. For the same mean weight, maximal acid output is much lower in subjects of both sexes over 50 than those under 50 years. The difference seems to be due to the fallingoff in acid output in older subjects.

Table V eliminates the variable factor of weight and gives comparative basal and maximal acid outputs in similar weight groups of subjects in the age groups 21-30 and 51-60 years. This once again shows that basal as well as maximal acid output for each of the weight groups of subjects between 51 and 60 years is lower by 2 to $2 \frac{1}{2}$ times than those in corresponding groups of subjects between 21 and 30 years.

INFLUENCE OF WEIGHT In the present series both basal and maximal acid output show a slight increase with increase in weight. In men this increase (Fig. 5) is slight (basal acid output $\mathrm{r}=+0.13, \mathrm{P}>0.8$; maximal $\mathrm{r}=+0 \cdot 10, \mathrm{P}>0.4)$ not significantly different from zero, but in females (Fig. 6) there is a significant increase (basal $\mathrm{r}=+0.31 ; \mathrm{P}<0.05$; maximal $r=+0.31, P<0.05)$.

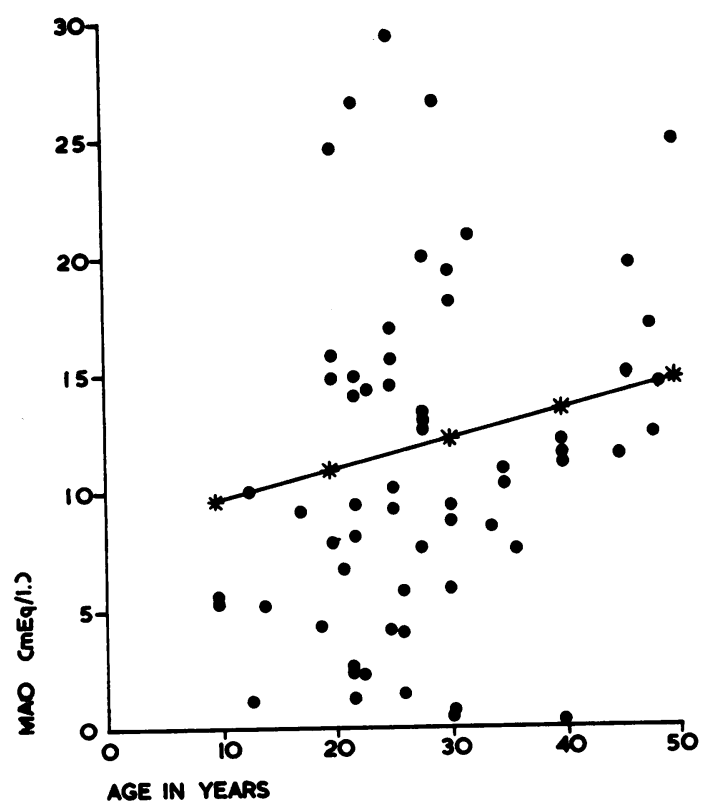

FIG. 3. Maximal acid output for men related to age.

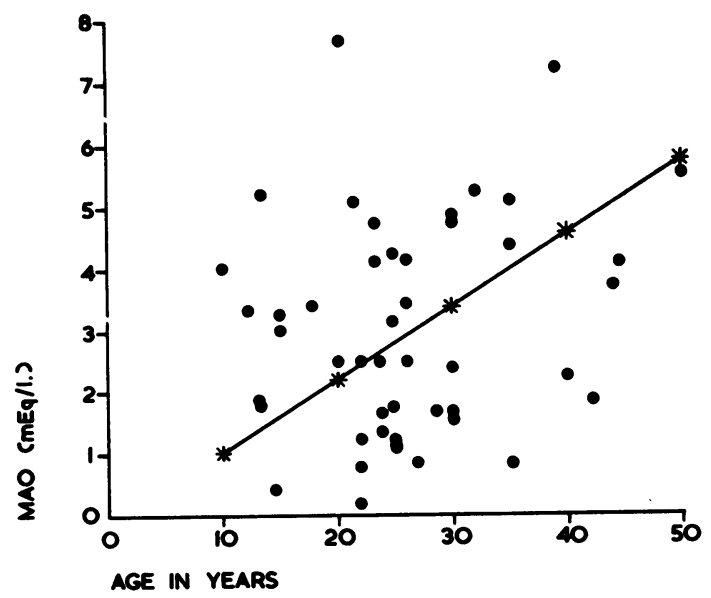

FIG. 4. Maximal acid output for women related to age.

However, the above-mentioned considerations do not eliminate the influence of age and thus do not reflect a direct relation of weights to acid output. It would be ideal to study large numbers of cases with different weights in each age group. However, due to the practical difficulty of getting normal subjects, the study was restricted to two age groups only. Table $V$ shows such a relationship in the two selected age groups. The results show that in both age groups in both sexes acid output increases with weight. In men, this increase in both age groups is 


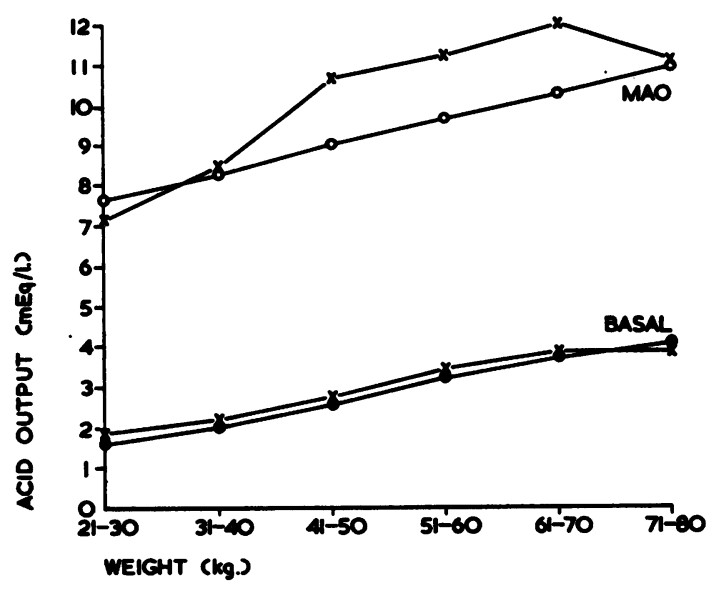

FIG. 5.

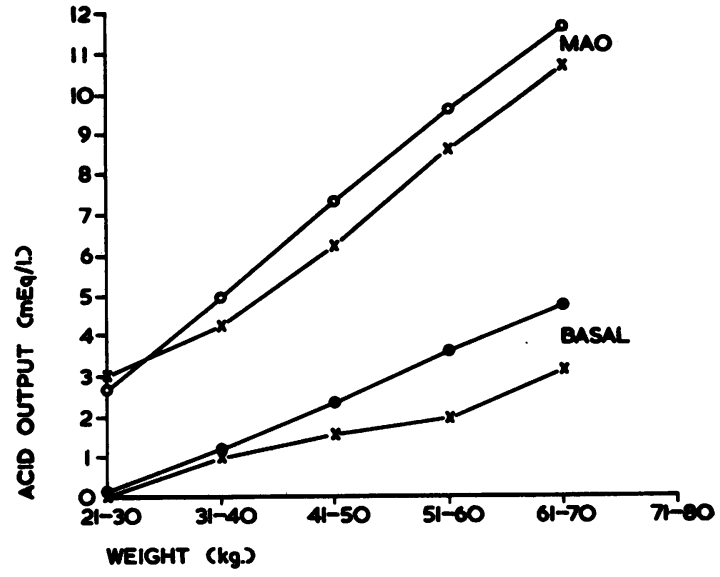

FIG. 6.

FIGS. 5 and 6. Maximal and basal output related to weight in men (Fig. 5) and women (Fig. 6).

not significant (21-30 years, basal acid output, $\mathrm{r}=+0.08, \mathrm{P}>0.6$; maximal, $\mathrm{r}=+0.02, \mathrm{P}>0.6$ : 51-60 years, basal acid output, $\mathrm{r}=+0.4, \mathrm{P}>0.2$; maximal, $\mathrm{r}=+0.25, \mathrm{P}>0.4)$. In women this increase is significant (21-30 years, basal acid output, $\mathrm{r}=+0.4, \mathrm{P}<0.05 ;$ maximal, $\mathrm{r}=+0.45, \mathrm{P}<0.05$ : 51-60 years, basal acid output, $\mathrm{r}=+0.9, \mathrm{P}<0.01$; maximal, $\mathrm{r}=+0.9, \mathrm{P}<0.01)$.

INFLUENCE OF DIET There was no significant difference in basal output $(P>0.05)$ or maximal acid output $(P>0.3)$ in vegetarian and non-vegetarian subjects (Table II).

INFLUENCE OF SMOKING There was no significant difference in basal acid output $(P>0.2)$ but there was a significant difference in maximal acid output $(\mathbf{P}<0.001)$ between smokers and non-smokers (Table II). However, such comparisons do not take into consideration the influence of other variables such as age and weight. To eliminate these variables, a comparison was made between smokers and nonsmokers of similar age groups, namely, 21-30 and 51-60 years. The mean weight of smokers and nonsmokers in these age groups was also fairly comparable (Table VI). In both age groups smokers seem to secrete more acid than non-smokers, the difference being more marked in maximal acid output than basal, but not significant in either case.

RESULTS OF KAY'S TESTS IN PATIENTS The mean basal secretion in duodenal ulcer subjects was for males: $5.21 \mathrm{mEq}$. (S.D. 5.83, range 1.62 to 17.53 ); for females, $4.45 \mathrm{mEq}$. (S.D. 0.5 , range 2.80 to 6.58 ) whereas the mean maximal acid output for males was $18.85 \mathrm{mEq}$. (S.D. 8.30, range 7.03 to 38.4 ); females: $18.76 \mathrm{mEq}$. (S.D. $2 \cdot 2$, range, 15.59 to 19.93 ). Acid output for various other conditions such as gastric ulcer, gastric carcinoma, stomal ulcers, and radiologically negative dyspepsias, is shown in Table II. The numbers of cases in these groups are too small to be conclusive.

\section{DISCUSSION}

The augmented histamine test is virtually free from any serious side effects, it is simple, and with experience anybody can perform it but, compared with the conventional fractional test meal, the method is more cumbersome and time consuming. Most patients do not mind it but some feel it to be an ordeal to have high doses of histamine and anti-

TABLE VI

ACID OUTPUT IN SMOKERS AND NON-SMOKERS IN TWO AGE GROUPS

\begin{tabular}{|c|c|c|c|c|c|c|c|}
\hline \multirow{2}{*}{$\begin{array}{l}\text { Age Group } \\
\text { (yr.) }\end{array}$} & \multirow[t]{2}{*}{ Subject } & \multirow{2}{*}{$\begin{array}{l}\text { No. of } \\
\text { Cases }\end{array}$} & \multirow{2}{*}{$\begin{array}{l}\text { Mean Weight } \\
\text { (kg.) }\end{array}$} & \multicolumn{2}{|c|}{ Acid Output (mEq.) } & \multicolumn{2}{|c|}{ Significance of Difference of Mean } \\
\hline & & & & Basal & Maximal & Basal & Maximal \\
\hline 21-30 & $\begin{array}{l}\text { Smokers } \\
\text { Non-smokers }\end{array}$ & $\begin{array}{l}16 \\
18\end{array}$ & $\begin{array}{l}51 \cdot 8 \\
49 \cdot 1\end{array}$ & $\begin{array}{l}4 \cdot 8 \\
3 \cdot 33\end{array}$ & $\begin{array}{c}12 \cdot 34 \\
9 \cdot 5\end{array}$ & $P>0.2$ & $P>0.2$ \\
\hline $51-60$ & $\begin{array}{l}\text { Smokers } \\
\text { Non-smokers }\end{array}$ & $\begin{array}{r}13 \\
7\end{array}$ & $\begin{array}{l}54 \cdot 4 \\
52 \cdot 1\end{array}$ & $\begin{array}{l}2 \cdot 67 \\
1 \cdot 11\end{array}$ & $\begin{array}{l}8 \cdot 77 \\
5 \cdot 24\end{array}$ & $P>0.1$ & $\mathbf{P}>\mathbf{0 . 2}$ \\
\hline
\end{tabular}


histaminic and to lie down in one position for nearly two hours with suction on. The test needs careful and constant supervision by a trained operator. On an average the test takes two and a half to three hours to be completed, during which time the patient cannot be left alone.

The conventional fractional test meal provides valuable information in a good number of cases but has its own fallacies and limitations. False negative results are more frequent with this test as the tube is not passed under fluoroscopic control nor a maximal stimulus given to parietal cells. Several authors (Levin et al., 1948a and 1948b; James and Pickering, 1949) have commented on the futility of passing the tube blindly. Our results again confirm this finding.

Sun, Shay, and Ciminera (1955) have reported that the coefficient of variation of hourly gastric acidity and volume of secretion on the same day varies widely. Baron (1963) has shown that volume and acid output of basal secretion is a poorly repeatable measurement of gastric function. Our results confirm these findings that whereas basal acid output is a poorly repeatable test, maximal acid output is a reliably repetitive measurement of gastric function both in normal subjects and in duodenal ulcer subjects.

Our results once again confirm the findings of all previous authors that acid output in normals is distributed over a wide range. Basal acid output in the present study is fairly comparable with results reported from the West which vary between $2 \cdot 2$ and $2.7 \mathrm{mEq}$. in controls and 5.4 and $6.8 \mathrm{mEq}$. in duodenal ulcer subjects (Marks, 1961). However, there is a significant difference in maximal acid output, namely, compared with 22 to $23 \mathrm{mEq}$. per hour in western controls and 37 to 39 in duodenal ulcer subjects (Marks, 1961) our values are 10.22 $\mathrm{mEq}$. for male controls and $\mathbf{1 7 . 8 5}$ for male duodenal ulcer subjects. Differences in acid output at various centres could depend upon age, sex, and body build. The average Indian weighs less than the average individual in the West. Most of our patients were slimmer, the average weight for the controls in both sexes being $50.6 \mathrm{~kg}$. It is not certain whether the differences in acid output are purely due to the differences in body build or whether any genetic, environmental, or dietetic factors play a part.

Most authors working on gastric secretions with various submaximal stimulation tests have reported that normal men secrete more acid then normal women. Kay (1953), Murray et al. (1957), Marks and Shay (1959), and Baron (1963) have reported that with the maximal histamine test acid output is significantly higher in males. However, most of these workers have not taken into consideration the effect of age and weight on acid output. Card (personal communication) believes that the sex difference can be explained by the larger body weight of males compared with females. The present studies show that there is a significantly higher acid output in men than in women of comparable age and weight groups and that sex differences cannot be explained by difference in weights only.

Bloomfield and Keefer (1928a, 1928b), using the submaximal dose of histamine $(0.01 \mathrm{mg}$. $/ \mathrm{kg}$.), found that both the acidity and volume of gastric secretion declined with age. Polland (1933) confirmed these findings and reported that the differences were more marked in men. Levin et al. (1951) have found a similar relationship in the basal secretion of normals. Baron (1963) found that basal and peak acidity declined with age significantly in women only. Most of these authors have not taken into consideration the influence of weight on acid output. The present studies show that there is a definite falling-off in acid output in subjects over 50 years in both sexes. However, no significant decline in basal secretion could be established with age in either sex. Maximal acid output showed an increase with age up to $\mathbf{5 0}$ years, which could be correlated with increase in weight and a decline after the age of 50 years, significant for women.

The present studies suggest that for both sexes there is an increase in basal and maximal acid output with increase in weight in normals which is more pronounced for women.

The present studies suggest that men who smoke have higher acid outputs than men who do not smoke. However, when a comparison was made between smokers and non-smokers of similar age and weight groups, differences were found not to be significant.

There are a number of variables which influence acid output in controls, namely, age, sex, and weight. The correlation of acid output with age or weight is more pronounced in females than in males, probably because in males certain other factors modifying this relationship have been overlooked. The influence of these variable factors make it difficult to give normal ranges for gastric acid output and results for any particular population will depend on its composition.

\section{SUMMARY}

The paper presents the results of 238 augmented histamine tests performed by the Kay technique in 208 hospital subjects in Bombay. The range of acid output in 151 normal Indian subjects, analysed by age, sex, body weight, and habits, is described. Values for acid output in 57 cases with various gastro-duodenal diseases are reported. 


\section{REFERENCES}

Adam, H. M., Card, W. I., Riddell, M. J., Roberts, M., Strong, J. A., and Woolf, B. (1954). Dose-response curves for the effect of histamine on acid gastric secretion in man. Brit. J. Pharmacol., 9, 329-334.

Baron, J. H. (1963). Studies of basal and peak acid output with an augmented histamine test. Gut, 4, 136-144.

Bloomfield, A. L., and Keefer, C. S. (1928a). Gastric acidity: relation to various factors such as age and physical fitness. J. clin. Invest., 5, 285-294.

-, - (1928b). Gastric motility and the volume of gastric secretion in man. Ibid., 5, 295-301.

Bruce, J., Card, W. I., Marks, I. N., and Sircus, W. (1959). The rationale of selective surgery in the treatment of duodenal ulcer. J. roy. Coll. Surg. Edinb., 4, 85-104.

James, A. H., and Pickering, G. W. (1949). The role of gastric acidity in the pathogenesis of peptic ulcer. Clin. Sci., 8, 181-210.

Kay, A. W. (1953). Effect of large doses of histamine on gastric secretion of $\mathrm{HCl}$ : an augmented histamine test. Brit. med. J., 2, 77-80.

Levin, E., Kirsner, J. B., and Palmer, W. L. (1951). A simple measure of gastric secretion in man: comparison of one hour basal secretion, histamine-secretion and 12 hour nocturnal gastric secretion. Gastroenterology, 19, 88-98.
Levin, E., Kirsner, J. B., Palmer, W. L., and Butler, C. (1948a). The variability and periodicity of the nocturnal gastric secretion in normal individuals. Ibid., 10, 939-951.

$-\ldots$ normal subjects and on patients with duodenal ulcer, gastric ulcer and gastric carcinoma. Arch. Surg., 56, 345356.

Marks, I. N. (1961). The augmented histamine test. Gastroenterology, 41, 599-603.

- Komarov, S. A., and Shay, H. (1960). Maximal acid secretory response to histamine and its relation to parietal cell mass in the dog. Amer. J. Physiol., 199, 579-588.

- and Shay, H. (1959). Observations on the pathogenesis of gastric ulcer. Lancet, 1, 1107-1111.

Murray, F. A., Erskine, J. P., and Fielding, J. (1957). Gastric secretion in pregnancy. J. Obstet. Gynec. Brit. Emp., 64, 373381.

Polland, W. S. (1933). Histamine test meals. An analysis of 988 consecutive tests. Arch. intern. Med., 51, 903-919.

Sun, D. C. H., Shay, H., and Ciminera, J. L. (1955). Relative effectiveness of anticholinergic drugs on basal gastric secretion. $J$. Amer. Med. Ass., 158, 713-718. 